This document is published in:

Review of Economic Dynamics (2000), 3 (3), 551-571.

DOI: http://dx.doi.org/10.1006/redy.1999.0074

C 2000 Academic Press. 


\title{
On the Political Economy of Latin American Land Reforms ${ }^{1}$
}

\author{
Antonia Díaz \\ Departamento de Fundamentos, del Análisis Económico, University of Alicante, \\ 03071 San Vicente del Raspeig, Alicante, Spain \\ E-mail: diaz@merlin.fae.ua.es
}

\begin{abstract}
Private ownership of land has been stressed in the development literature as key to increasing productivity in the agricultural sector. The beneficiaries of the redistributive land reforms undertaken in many Latin American countries, however, did not receive the individual property right of the land. This paper suggests that this type of reform was a measure intended to favor not the peasantry, but the landed elite of those countries. It is shown that if land is the abundant factor land rent is decreasing with the total amount of privately owned land. Thus, the landed elite favored giving the peasants land under a restricted ownership regime. Journal of Economic Literature Classification Numbers: D23, D72, O17, Q15
\end{abstract}

\section{INTRODUCTION}

Redistributive land reforms have been used in many developing countries as a means of improving the living standards of the peasantry as well as to increase productivity in the agricultural sector. Moreover, individual ownership of the land has been stressed in the development literature as key to achieving those two objectives (see Binswanger et al., 1993, 1995). The beneficiaries of the land reforms in many Latin American countries, such as Mexico, Peru, or Bolivia, however, did not receive individual ownership of the land granted. The question addressed in this paper is why the society in those countries chose an inefficient ownership system instead of the efficient private ownership regime.

\footnotetext{
${ }^{1}$ The author thanks the editor and an anonymous referee for helpful suggestions. Support from the Instituto Valenciano de Investigaciones Económicas and the Spanish Ministry of Education, DGES project PB96-0339, is gratefully acknowledged.
} 
The literature on land reform has stressed the link between level of development and a more egalitarian distribution of land across the members of society. See, for instance, Binswanger et al., (1993, 1995), Moene (1992), Ray and Streufert (1993), or Besley and Burgess (1998). A few authors, such as Grossman (1994) and Horowitz (1993), have analyzed why a society decides to undergo land reform, but have abstracted from the ownership regime under which the land is transferred to the peasants. This is precisely the main focus of this paper.

Various authors, such as Barraclough and Collarte (1973), De Janvry (1981), Ekstein et al. (1978), Heath et al. (1969), and Kay (1982), have studied the agrarian structure and the land reforms of the countries mentioned. There are three features of the Latin American land reforms that are specific to that area: First, the reforms took place as a response to the uprisings of landless peasants. Second, the reforms ended the system of semiserfdom prevailing in the agrarian sector. ${ }^{2}$ Under this system the peasants were divided into two groups: Those who had lifelong attachment to the hacienda (the estate of the big landowner) and those who were temporary workers. This system had evolved into a social norm: Some peasants worked for the hacendados and others, at most, could do so as temporary workers (see Heath et al., 1969). Third, the landed elite retained sufficient political power so that they could influence the regime under which the peasants received the land. ${ }^{3}$

I am going to use the Mexican case as the illustrative example, but the other countries mentioned have had similar experiences. The former owners were not compensated for the expropriation of their land. The entity that received the land was the community of peasants. The members of the community worked on the land, the ejido, and distributed the yield equally among themselves. The land could not be transferred in any manner and the peasants were forbidden to hire labor services. The right to use the land passed from one generation to the next one. If a holder of a plot of land did not cultivate it, the right to cultivate it was given to someone else. The latter rule applied also to land held by private owners. ${ }^{4}$

${ }^{2}$ By a system of semiserfdom I mean the production relations operating in the manorial estate, known in the development literature as debt peonage or bonded labor services. See Binswanger et al. (1995).

${ }^{3}$ This view about the political power of the landed elite underlies the studies on the agrarian structure of the countries mentioned. For a clear and short discussion of it see Ray (1998).

${ }^{4}$ Peru had an experience similar to that of Mexico. The only difference in Bolivia is that peasants received individual plots instead of communal lands. They were not forbidden to hire workers but the size of the plots was so small that they were precluded from hiring labor services de facto. 
Before the reform in Mexico, 5\% of the population held $80 \%$ of the farmland. In 1990, the ejidos controlled around $50 \%$ of the agricultural land..$^{5}$ Small private farms (below 5 hectares) constitute less than $10 \%$ of the total farmland (see Otsuka et al., 1992). The evidence shows that the ejidos' performance is worse than that of the private sector. Yates (1981) uses data provided by Nguyen and Martinez Saldivar (1979) and estimates that the yield per harvested hectare in the ejidos was between 50 and $80 \%$ lower than that of comparable private farms. Moreover, Martinez Hernandez (1992) reports that during the period 1976-1983 the average income of an ejido member was only $47.6 \%$ of the minimum wage. In $199074.1 \%$ of the ejidatarios received an income lower than minimum wage.

The question I address is why a society that has already chosen to expropriate land owned by the landed elite, would give the land to the peasants under an inefficient restricted ownership regime. In particular, given the evidence just cited, it is not obvious why the peasants preferred to receive land under such a regime instead of working in the privately owned lands. ${ }^{6}$ This paper suggests that the landed elite, facing the expropriation of their land, preferred the peasants to receive the land without full rights. The reason for this preference is that, when land is sufficiently abundant, as in the Latin American countries mentioned, rents of the land are maximized when not all the land is privately owned.

To illustrate this idea I develop a model economy populated by two types of individuals: Aristocrats (the hacendados) and peasants. I take as given that the system of semiserfdom has been eliminated. The social unrest that led to the expropriation of the aristocrats' land is modeled as if the members of the society could vote on the amount of land to be expropriated. In the equilibrium of the model, the aristocrats prefer not all the land to be privately owned. By exploiting the prevailing social norm, the aristocrats are able to divide the peasants into two groups: Those who can work for the landed elite, and those whose only choice is to farm expropriated land. These two groups have opposite preferences on the amount of expropriated land: Those who can work for the aristocrats want none; those who cannot want more land expropriated than the aristocrats want. In this way, the aristocrats can build enough of a constituency so their most preferred outcome is chosen by the society.

The rest of the paper is organized as follows. In Section 2, I describe the environment. Section 3 studies the model economy after the ownership

\footnotetext{
${ }^{5}$ In Bolivia, $30 \%$ of the farmland was distributed to $35 \%$ of the peasant families in the late 1950 's. In Peru, around $50 \%$ of the agricultural land was transferred to $10 \%$ of the peasant families in 1973. See Wilkie $(1974,1993)$.

${ }^{6}$ Brannon and Baklanoff (1984) describe the process of land reform in Yucatán: "conditions [at the beginning of the reform] became so chaotic that some groups of ejidatarios mutinied and demanded a return to the old system."
} 
regime on land has been chosen. Section 4 analyzes under which conditions the equilibrium of the model resembles a Latin America land reform. In Section 5 I comment on some modeling assumptions. Section 6 studies the relationship between population size and the ownership regime chosen. Section 7 concludes.

\section{THE ENVIRONMENT}

The economy lasts one period and is populated by a measure $N$ individuals. They value the consumption of a composite commodity, $y$, and do not value leisure. Each individual is endowed with one unit of time. The consumption good is produced using land and the individuals' endowments of time. There is a group of individuals, called aristocrats - who are to resemble the group of the hacendados-whose measure is $A$. The rest of the individuals are called peasants. The total amount of farmland in the economy is denoted as $\bar{L}$. Each aristocrat has $\bar{L} / A$ units of land at his disposal. A land reform is modeled as an expropriation and a reallocation of land. All the individuals vote on the amount of land to be kept by the aristocrats. The rest of the land is expropriated. For simplicity, I have assumed that all votes are equally weighted. Land cannot be left uncultivated. The land kept by the aristocrats is called private land. The expropriated land is called communal land and is left to those peasants who want to cultivate it under a common property regime. The group of the aristocrats, before the voting takes place, collectively choose those peasants who can work for them. They are called private workers and can either offer their labor services to any aristocrat or cultivate communal land. Those whose only choice is to farm communal land are called communal workers. This division is sustained by the social norms prevailing in the society, as mentioned in the Introduction. The model is organized in the following stages:

First Stage: The Division of the Peasants. The aristocrats, collectively, decide the number of private workers, $P$, who, for simplicity, are randomly chosen across all peasants. The rest of the peasants, $C$, are communal workers. The aristocrats commit to not hire any communal worker. This commitment is sustained by the existing social norm: some peasants could work for the aristocrats, and the rest could not.

Second Stage: The Expropriation of Land. All the individuals vote on the amount of private land, $L_{\mathrm{p}}$. Each aristocrat is expropriated, without compensation, $\left(\bar{L}-L_{\mathrm{p}}\right) / A$ units of land. 
Third Stage: The Competitive Equilibrium. The private workers decide whether to work for an aristocrat or cultivate communal land, $\bar{L}-L_{\mathrm{p}}$, along with the communal workers. The aristocrats compete to hire private workers. Individuals produce and consume.

Throughout the paper, the private sector is that in which land is privately owned, comprising aristocrats and those private workers who work for the aristocrats. The communal sector is the sector in which no individual has individual rights to the land and is composed of those peasants who cultivate communal land.

Each aristocrat has access to the production technology,

$$
F_{\mathrm{p}}(l, n)=\left(\gamma l^{\rho}+(1-\gamma) n^{\rho}\right)^{1 / \rho}, \quad \rho<0,
$$

where $l$ is private land and $n$ denotes labor time. The parameter $\rho$ is less than zero; thus, the elasticity of substitution between land and labor is less than one. For simplicity, I assume that the return to managerial time is zero. The private workers who work for an aristocrat receive a wage, $y_{\mathrm{p}}$. The rest of the yield is the rent received by the aristocrat, $y_{a}$. The peasants who farm communal land use the technology

$$
F_{\mathrm{c}}(l, n)=\theta\left(\gamma l^{\rho}+(1-\gamma) n^{\rho}\right)^{1 / \rho}, \quad \rho<0, \theta \in(0,1) .
$$

Each peasant in the communal sector receives the average product as a rent, denoted as $y_{\mathrm{c}}$. I assume that the technology used in the communal sector is less productive than that used in the private sector. This lower productivity is meant to capture the fact that communal organization of the production process is less efficient than private organization. This is modeled as the parameter $\theta$ being less than one.

\section{THE COMPETITIVE EQUILIBRIUM}

In this section I analyze the competitive equilibrium of the model economy for a given division of the peasants and a given amount of expropriated land. Thus, $P$ and $L_{\mathrm{p}}$ are given. At the beginning of this stage, private workers decide whether to stay in the private sector or to join the communal sector. Let us denote as $N_{\mathrm{p}}$ the number of private workers who stay in the private sector. This number is a function of $L_{\mathrm{p}}$ and $P$. Since private workers can move freely and the technology displays constant returns to scale, their wage is determined by the aggregate 
variables,

$$
y_{\mathrm{p}}\left(P, L_{\mathrm{p}}\right)=\frac{\partial F_{\mathrm{p}}\left(L_{\mathrm{p}}, N_{\mathrm{p}}\right)}{\partial N_{\mathrm{p}}} .
$$

It is assumed that, although the aristocrats can commit to not hire communal workers, they cannot enforce a collusive agreement to pay the private workers less than their marginal product. The fact that labor is the scarce factor makes aristocrats compete for workers and, therefore, they end up paying the marginal product of labor. The discussion of the reasonableness of these assumptions is postponed to Section 5.

Each aristocrat receives a fraction $1 / A$ of the amount of private land and, hence, the same fraction of the aggregate rents of land. Their consumption is

$$
y_{\mathrm{a}}\left(P, L_{\mathrm{p}}\right)=\frac{L_{\mathrm{p}}}{A} \cdot \frac{\partial F_{\mathrm{p}}\left(L_{\mathrm{p}}, N_{\mathrm{p}}\right)}{\partial L_{\mathrm{p}}} .
$$

The number of peasants in the communal sector is $N_{\mathrm{c}}=C+P-N_{\mathrm{p}}$. Each one of them receives the average yield in the communal sector,

$$
y_{\mathrm{c}}\left(P, L_{\mathrm{p}}\right)=\frac{1}{N_{\mathrm{c}}} \cdot F_{\mathrm{c}}\left(\bar{L}-L_{\mathrm{p}}, N_{\mathrm{c}}\right) \text {. }
$$

If all the private workers stay in the private sector, $N_{\mathrm{p}}=P$, we have that $y_{\mathrm{p}}\left(P, L_{\mathrm{p}}\right) \geq y_{\mathrm{c}}\left(P, L_{\mathrm{p}}\right)$. If $N_{\mathrm{p}}<P$, the number $N_{\mathrm{p}}$ must be such that $y_{\mathrm{p}}\left(P, L_{\mathrm{p}}\right)=y_{\mathrm{c}}\left(P, L_{\mathrm{p}}\right)$. Thus, the number of private workers that stay in the private sector is a function of the amount of private land, $N_{\mathrm{p}}=\eta\left(P, L_{\mathrm{p}}\right)$. There exists an amount of land $\lambda(P)$ such that if $L_{\mathrm{p}} \geq \lambda(P)$ all the private workers remain working for the aristocrats, $N_{\mathrm{p}}=P$; otherwise some of them join the communal sector, $N_{\mathrm{p}}<P{ }^{7}$ This will be important to determine the individuals' preferences on the amount of private land.

Now we turn to analyzing the aristocrats' rents. For any given number of workers in the private sector, maximization of (2) implies that the land-labor ratio must be equal to

$$
\phi=\left(\frac{-\gamma}{\rho(1-\gamma)}\right)^{-1 / \rho}
$$

${ }^{7}$ These two functions, $\eta$ and $\lambda$, are defined in Lemma 1 in the Appendix. 
that is,

$$
\frac{\partial y_{\mathrm{a}}(n, \phi n)}{\partial l}=0
$$

This will be important to understanding the aristocrats' preferences on the amount of privately owned land, which is analyzed in the next section.

\section{A LATIN AMERICAN LAND REFORM}

In this section I analyze the conditions under which the equilibrium of the model captures the main features of a Latin American land reform. The parameters are restricted to the subset defined by the following assumptions:

Assumption 1. A<N/2.

Assumption 2. $\theta \leq(1-\rho)^{1-\theta / \rho}$.

Assumption 3. $\left(\frac{1-\theta}{-\rho \theta}\right)^{-1 / \rho} \geq 2$.

Assumption 4. $N<\bar{L} / \phi+A$.

Assumption 1 rules out the equilibrium in which the aristocrats are the majority of the population. ${ }^{8}$ Assumption 2 implies that cultivating land communally is very inefficient. Assumptions 2 and 3 together impose a lower bound $\bar{\rho}$ to the possible values of $\rho$. This bound is less than -1 . These two assumptions will greatly simplify the analysis. Assumption 4 tells us that land is the relatively abundant factor, as in the Latin American countries we are focusing on.

\subsection{The Expropriation of Land}

In this section I analyze the individuals' preferences on the amount of privately owned land. Particularly, I shed light on why the aristocrats prefer that not all the land be privately owned.

Proposition 1. Under Assumptions 1-4, the private workers' rent is a single-peaked function of the amount of private land. The private workers' most preferred voting outcome is $\bar{L}$, for any number of private workers $P$.

${ }^{8}$ I do not discuss this case because the aristocrats are to resemble the landed elite of a typical Latin American country, who owned most of the farm land and usually composed a very small fraction of the population. In the countries mentioned in the Introduction the landed elite composed about $5 \%$ of the population. 
Proposition 1 states that the private workers, rather than expropriating any land, prefer the aristocrats to cultivate all the land as a means to raise their wage. The idea is the following: The wage only depends on the land-labor ratio in the private sector, $L_{\mathrm{p}} / N_{\mathrm{p}}$. For any amount of private land that satisfies $L_{\mathrm{p}} \geq \lambda(P)$ all the private workers stay in the private sector, $N_{\mathrm{p}}=P$, which implies that $L_{\mathrm{p}} / N_{\mathrm{p}}$ increases with $L_{\mathrm{p}}$. For any amount of private land such that $L_{\mathrm{p}}<\lambda(P)$ some private workers join the communal sector, $N_{\mathrm{p}}<P$. The land-labor ratio could decrease or increase with $L_{\mathrm{p}}$. It is shown in the Appendix that it is increasing.

PROPOSITION 2. Under Assumptions 1-4, the communal workers' rent is single-peaked. Their most preferred voting outcome is an amount of private land $\lambda(P)$ that satisfies $0<\lambda(P)<\bar{L}$, for any $P$.

Since the wage in the private sector strictly increases with the amount of private land, it follows that for any amount or private land less than or equal to $\lambda(P)$ the rent in the communal sector, $y_{\mathrm{c}}\left(P, L_{\mathrm{p}}\right)$, increases with the amount of private land, too. For any $L_{\mathrm{p}}>\lambda(P)$ all the private workers stay in the private sector, $N_{\mathrm{p}}=P$ and $y_{\mathrm{p}}>y_{\mathrm{c}}$. Any increase in the amount of private land decreases the land-labor ratio in the communal sector and reduces the average yield. Therefore, $y_{\mathrm{c}}$ has a maximum at $\lambda(P)$. Thus, communal workers, who had no other choice but farming communal land, prefer the aristocrats to keep some land, so that the private workers stay in the private sector. Otherwise, the average product in the communal sector would be too small.

Proposition 3. Under Assumptions 1-4, the aristocrats' rent is singlepeaked. The aristocrats' most preferred outcome is an amount of private land $\phi P$ that satisfies $0<\phi P<\bar{L}$ for any $P$.

Assumption 2 implies that whenever the land-labor ratio in the private sector is $\phi$, the wage is greater than the average yield in the communal sector. This is equivalent to stating that $\phi P>\lambda(P)$, for any $P$. We know that for any $L_{\mathrm{p}} \geq \lambda(P)$, at the competitive equilibrium stage all the private workers decide to stay in the formal sector, $N_{\mathrm{p}}=P$. I showed in Section 3 that $\phi$ is the land-labor ratio for which the aristocrats' rents are maximized (see Eq. (4)). Thus, the aristocrats prefer $\phi P$ to any amount of land greater than $\lambda(P)$. It is shown in the Appendix that $y_{\mathrm{a}}$ is an increasing function of $L_{\mathrm{p}}$ in the interval $(0, \lambda(P))$. Thus, the aristocrats most preferred outcome is $\phi P$ (which is lower than $\bar{L}$, by Assumption 4).

Proposition 3 states that the aristocrats prefer to have expropriated some land rather than to cultivate it. Let us analyze the rationale for their behavior. We have assumed that the elasticity of substitution between land and labor is less than one and that land is the relatively abundant factor. 
Private workers are paid their marginal product. These three assumptions imply that if too much land competes for workers, the rent paid to private land decreases. To rise the land rent the wage must be depressed. To prevent the wage from raising, the aristocrats would like to leave land unused, but unused land is expropriated and given to the peasants. The expropriated land is cultivated under a communal regime, where peasants are forbidden to hire workers, so communal land does not compete for workers. Furthermore, if the wage paid in the private sector is high enough (which is the case if the land-labor ratio in the private sector is equal to $\phi)$, no private worker wants to join the communal sector.

We have shown that the individuals' rents are single-peaked functions of the amount of private land; thus, we can apply the median voter theorem (see Mueller, 1989). The next proposition describes the voting outcome for a given number of private workers, $P$.

Proposition 4. The amount of land expropriated is a function of the number of private workers and satisfies $L_{\mathrm{p}}(P)=\lambda(P)$ if $P<\frac{N}{2}-A, L_{\mathrm{p}}(P)$ $=\phi P$ if $\frac{N}{2}-A \leq P \leq \frac{N}{2}$, and $L_{\mathrm{p}}(P)=\bar{L}$ if $P>\frac{N}{2}$.

Communal workers prefer to have a greater amount of land to be expropriated than the aristocrats, and the private workers want none. The three candidates to be the voting outcome satisfy $\lambda(P)<\phi P<\bar{L}$. Since preferences are single peaked, it follows that communal workers prefer $\phi P$ to $\bar{L}$ and private workers prefer $\phi P$ to $\lambda(P)$. If the communal workers are the majority of the population, $\lambda(P)$ units of land become private and the rest is expropriated. If private workers are the majority of the population, the aristocrats keep all the land, but they have to cultivate it, as was required by the land reform laws in Bolivia, Mexico, and Peru. If neither group is the majority, the aristocrats keep $\phi P$ units of land, and the rest becomes communal land. ${ }^{9}$

\subsection{The Division of the Peasants}

This section analyzes the division of the peasants between private and communal workers under which the equilibrium of the model resembles a Latin American land reform. We have seen that the amount of expropriated land depends on the number of private workers. To determine this

\footnotetext{
${ }^{9}$ I have assumed that all votes are equally weighted. This amounts to assuming that peasants and aristocrats have the same power in the society. To model different political power I could have assumed that one peasant's vote is equivalent to $\delta$ aristocrats' votes, $\delta \in[0,1]$. In that case, the aristocrats would be the median voter if $\frac{1}{2} N-\frac{1-\delta}{2 \delta} A \leq P \leq \frac{1}{2} N$ $+\frac{1-\delta}{2 \delta} A$.
} 
number the aristocrats solve the problem

$$
\max _{P \in[0, N-A]} y_{\mathrm{a}}\left(P, L_{\mathrm{p}}(P)\right) .
$$

If the aristocrats chose $P<N / 2-A$, the communal workers would be the majority of the population and only $\lambda(P)$ units of land would remain private; as a consequence, all the private workers would stay in the private sector. In that case, the operating land-labor ratio in the private sector, $\frac{\lambda(P)}{P}$, would be lower than the ratio that maximized land rents, $\phi$. Therefore, the aristocrats never choose a number of private workers lower than $N / 2-A$. If $P$ were chosen so that $N / 2-A \leq P \leq N / 2$, the operating land-labor ratio would be $\phi$ and the aristocrat's rent would be a strictly increasing function of the number of private workers, since

$$
y_{\mathrm{a}}(P, \phi P)=-\rho \frac{P}{A}(1-\gamma)^{1 / \rho}(1-\rho)^{(1-\rho) / \rho} .
$$

It follows that $P \geq N / 2$; that is, private workers constitute at least half of the population. Now let us assume that the aristocrats choose $P>N / 2$. In that case, all land becomes private and the aristocrats are forced to cultivate it. The aristocrats' rent will be

$$
y_{\mathrm{a}}(P, \bar{L})=\frac{P}{A} \gamma\left(\frac{\bar{L}}{P}\right)^{\rho}\left(\gamma\left(\frac{\bar{L}}{P}\right)^{\rho}+(1-\gamma)\right)^{(1-\rho) / \rho},
$$

which is also increasing with the number of private workers. It follows that $P \in\{N / 2, N-A\}$. Notice that if $P=N-A$, given Assumption 4, the land-labor ratio $\bar{L} /(N-A)$ is greater than $\phi$. The increase in yield brought by the use of larger amounts of both inputs may or may not compensate for the decrease in land rents implied by a larger land-labor ratio. If the amount of per capita land, $\bar{L} / N$, is sufficiently large the aristocrats choose $P=N / 2$, regardless of the size of the aristocracy. If that is not the case, the choice depends on the size of the aristocracy relative to the total population. The following propositions state this result.

Proposition 5. There exists $\chi>1$, such that if $\bar{L} / N \geq \phi \chi$ the number of private workers is $P=N / 2$ and the amount of private land is $L_{\mathrm{p}}=\phi N / 2$.

PROPOSITION 6. If $\bar{L} / N<\phi \chi$ there exists a critical number of aristocrats, $N_{\mathrm{a}}(N)$, such that for any $A \geq N_{\mathrm{a}}(N)$ the number of private workers is $P=N / 2$ and the amount of private land is $L_{\mathrm{p}}=\phi N / 2$. If $A<N_{\mathrm{a}}(N)$, the number of private workers is $P=N-A$ and the amount of private land is 
$L_{\mathrm{p}}=\bar{L}$. The number $N_{\mathrm{a}}(N)$ satisfies $0 \leq N_{\mathrm{a}}(N)<N / 2$ and monotonically increases with the size of the population.

I identify the Latin American countries studied as countries with the following features: First, the population and technological assumptions are as in Assumptions 1, 2, and 3. Second, land is very abundant, $N \leq \bar{L} / \phi \chi$. This upper bound is strictly less than $\bar{L} / \phi+A$, which was the upper bound stated in Assumption 4. Third, the prevailing social norm sustains a division of the peasants characterized by $N / 2-A \leq P \leq N / 2$.

The rationale I propose for the Latin America land reforms is the following: Before the reform, a semiserfdom system prevailed and the living standard of the peasants was so low that social unrest ensued. The peasants demanded freedom, higher wages, and the possibility to cultivate land by themselves. The end of the semiserfdom system brought to an end to the ability of the aristocrats to reduce to a minimum the rent paid to the peasants. The possibility of leaving land unused as a means of reducing labor rents was then more crucial for them. That was banned by the land reform laws: Any unused land was expropriated and given to the peasants who claimed it. Thus, the problem was not to preserve all the land, but how much land to have expropriated. The aristocrats colluded to not hire some peasants. This collusion was sustained by the prevailing social norm: Some peasants could work for the aristocrats - because their families had done so for generations, etc.- - and others could not. This way, the peasants were divided into two groups with opposite preferences on the amount of land to be expropriated. Given this opposition, the aristocrats could build enough political support so that their most preferred outcome was chosen by the society. ${ }^{10}$

Under this light, how are we to interpret the equilibrium in which all the peasants become private workers, $P=N-A$ ? There are two interpretations. First, the one I have used so far: The aristocrats are able to break up the social norm and allow all the peasants to move freely across sectors. They do so if the number of peasants is sufficiently large, $\bar{L} / N<\phi \chi$ and $A<N_{\mathrm{a}}(N)$, so that the decrease in land rents brought by the use of a large amount of land is more than compensated for by the increase due to a larger amount of labor services. The second interpretation has to do with the effectiveness of the social norm. If it has become very weak, aristocrats are not able to commit to not hire communal workers. In that case, given

${ }^{10}$ In the equilibrium studied the wage paid to the private workers is greater than the rent obtained in the communal sector, $y_{\mathrm{p}}(P, L(P))>y_{\mathrm{c}}(P, L(P))$. Private workers are paid above their reservation wage. This gap depends on $\theta$. Notice that the greater is $\theta$, the higher is the productivity in the communal sector for any amount of land. Thus, the greater is $\theta$, the smaller is the gap and the larger must be the amount of privately owned land to prevent private workers from joining the communal sector. 
any amount of private land, competition for workers implies that private and communal workers are paid equally. Peasants can foresee this and rationally vote for all the land to become private. Consequently, aristocrats choose $P=N-A .^{11}$

\subsection{On the Number of Landowners}

So far, I have assumed that only aristocrats can own land. I have modeled private ownership as being able to hire workers. Now I am going to analyze why peasants were not given individual ownership of the land expropriated. Let us assume now that the peasants can become landowners. I am going to model it as if the aristocrats can decide, before the expropriation of land takes place, the number of peasants who are going to receive land with total rights. I am going to call them small owners and denote their number by $S$. All individuals vote on the amount of land to be privately owned, $L_{\mathrm{p}}$. Once it has been voted, each aristocrat is expropriated $\bar{L} / A-\pi_{\mathrm{a}} L_{\mathrm{p}}$ units of land. An aristocrat keeps $\pi_{\mathrm{a}} L_{\mathrm{p}}$ units and each small owner is given $\pi_{\mathrm{s}} L_{\mathrm{p}}$ units. We have that $\pi_{\mathrm{a}} A+\pi_{\mathrm{s}} S=1$. Like the aristocrats, the group of small owners commit, at the production stage, to hire only private workers.

The timing is as follows: At the division stage, the aristocrats choose which workers are to be private and which peasants are to be small owners. The other two stages are identical to those of the previous version of the model. At the voting stage and the production stage, small owners and aristocrats behave identically in every respect. As opposed to private workers, just for simplicity, small owners cannot join the communal sector.

Since aristocrats and small owners behave identically, the number of private workers and the amount of private land chosen in an economy in which there are $A$ aristocrats and $S$ small owners are equal to those chosen in an economy in which the number of aristocrats is $A+S$ and the peasants cannot own land. The aristocrats always choose $S$ such that the total number of owners is less than or equal to $N / 2$, since for $S \geq N / 2-A$ the landowners are always the median voters. To analyze the equilibrium outcome in this model economy, I am going to assume, first, that the number of small owners is fixed, and I will show that the aristocrats' rent is a decreasing function of the number of small owners and of the amount of land given to them.

${ }^{11}$ This result is implied by Proposition 1 that states that private workers prefer all the land to be privately owned for any number of private workers. This proposition holds if Assumption 4 is satisfied. We will see in Section 6 that if population is sufficiently large, peasants prefer all the land to be expropriated. 
For any population size that satisfies either $N \leq \bar{L} /(\phi \chi)$ or $\bar{L} /(\phi \chi)<$ $N<\bar{L} / \phi+A$ and $A+S \geq N_{\mathrm{a}}(N)$, the number of private workers is $N / 2$ and the amount of private land is $\phi N / 2$. The aristocrats' rent is

$$
-\pi_{i} \cdot \rho \frac{N}{2}(1-\gamma)^{1 / \rho}(1-\rho)^{1-\rho / \rho}, \quad i=\mathrm{a}, \mathrm{s},
$$

which is decreasing with the number of small owners and also with the fraction of the private land given to the small owners. If $\bar{L} /(\phi \chi)<N<$ $\bar{L} / \phi+A$ and $A+S<N_{\mathrm{a}}(N)$, the aristocrats' rent is

$$
\pi_{i} \cdot \gamma \bar{L}^{\rho}\left(\gamma \bar{L}^{\rho}+(1-\gamma)(N-A-S)^{\rho}\right)^{(1-\rho) / \rho}, \quad i=\mathrm{a}, \mathrm{s},
$$

which is also decreasing with the number of small owners and the amount of land given to them. Hence, the number of small owners is zero. Thus, if the hacendados, the group that I have called aristocrats, have the power to decide the nature of the land reform, they never allow the peasants to own land. The hacendados would allow the peasants to become owners if they needed enough constituency to become the median voter. Since land is abundant and the productivity in the informal sector is very low, the aristocrats obtain enough support from formal workers, who prefer $\phi P$ to the outcome most preferred by the informal workers, $\lambda(P)$. Thus, the hacendados do not need the small owners and they are better off whenever the group of landowners is a very small fraction of the population.

There is no formal evidence for this hypothesis in the Mexican case, but there exists some anecdotal evidence from the beginning of the agrarian reform in Peru in the early 1970's narrated by De Soto (1989). Right before the reform was enacted, owners of land in the outskirts of Lima engaged with settlers in organizing fictitious invasions of the land, receiving in exchange, "more money than expropriation would have brought but less than the normal [sale] price" (p. 30). If the owners were better off having the land invaded instead of selling it, it must be because after the sale the new owner has full rights on the land, whereas after the invasion he or she does not.

This analysis also suggests that if the aristocrats had allowed some peasants to become owners of land, they would have had all the incentives to give the peasants a property as small as possible. In that case, the peasants very well would have ended up being worse off than joining the communal sector. The Mexican history gives us a hint of why the private ownership of the land was never claimed by the beneficiaries of the reform: Mendieta y Nuñez (1937) reports that in the middle of the 19th century the Mexican government, urged by the need to raise taxes, issued 
several acts. First, the Catholic Church, exempted from paying taxes, had expropriated a large fraction of its land. The aim was to transfer it under an individual property regime to the tenants, but such high taxes were imposed that they mostly sold their property to the big landowners, who could evade taxes easily. In many cases, the big landowners used violence to force the tenants to sell them the land. Second, the community, the base of the agrarian property among the peasants descended from the Indians, was declared not a legal entity and, therefore, unable to own land. Under the Act of Waste Land (1857) the Indian communal lands were appropriable by anyone who denounced the existence of wasteland to the authorities. Later on, the government tried to correct this situation by ruling that the peasants who traditionally used the Indian communal lands were to receive the individual property of the land, on the same basis as the tenants of the lands of the Church. The result was the same.

\section{SOCIAL NORMS AND THE ARISTOCRATS' POWER}

We have seen that, in the subset of the parameter space considered, the equilibrium of the model matches the nature of a Latin American land reform. Two assumptions are key to obtain this result: The ability of the aristocrats to commit to not hiring communal workers and the competition for private workers at the competitive (third) stage. The first assumption is based on social norms inherited from the prereform times. In this section I present some historical evidence on the agrarian structure of a typical Latin American country and argue that these two assumptions capture its main features.

The work by Bazant (1977) is a case study of a Mexican hacienda, Bocas, in San Luis Potosí, right before the revolution of 1915. There were two types of workers: peons and tenants. The former were permanent workers on the hacienda and the latter were peasants who used some of the land that the hacendado left uncultivated. The tenants paid a rent for the land and occasionally did some work for the hacendado. The author's account of the wage paid to peons and the income of the tenants suggests that peons' income was at least $20 \%$ higher than that of the tenants. He also reports the permanent struggle of the tenants to pay a lower rent to the owner of Bocas. At the end of the study the author offers anecdotal evidence of owners of other haciendas offering to the peons of Bocas higher wages than those they were receiving. After that, peons of Bocas had a raise in their wage.

This piece of evidence suggests that assuming aristocrats are not able to pay private workers their reservation wage is not unreasonable. In the model private workers are paid their marginal product. This assumption is 
not critical for the model. What is essential is that the wage is an increasing function of the land-labor ratio in the private sector. Sadoulet (1992) shows that in model economies that share the main characteristics of the Latin American countries mentioned, an efficient contract would feature a wage increasing with the amount of land.

The historical account of Bazant also suggests that the equilibrium division of the peasants in the model resembles reasonably well the division prevailing before the reforms. (Private workers are to be identified with peons and communal workers with tenants.) I take the view that that organization had already been internalized as a social norm at the time of the land reform. This social norm is the key feature of the economy that sustains a division of the peasants into two groups with opposite interests on the amount of expropriated land. The model also shows that if aristocrats break up that social norm-allowing all the peasants to be private workers - or if the social norm is eroded so that they are unable to commit to not hiring communal workers, all the land becomes privately owned.

I have ruled out the possibility of private and communal workers colluding. If they could do so, they would vote for all the land to be privately owned by the aristocrats. I take the view that the social norm impedes private and communal workers colluding. Nevertheless, when the size of the population is sufficiently high this social norm is no longer effective. The next section illustrates this point.

\section{THE ROLE OF POPULATION SIZE}

In Section 4 we have seen that the aristocrats, exploiting the prevailing social norm in the society, are able to divide the peasants into two groups with opposite preferences on private land. Given this opposition, the landowners arise as the median voter. This "divide and conquer" policy is not always possible. If the size of the population is sufficiently large, private and communal workers' preferences are maximized when all land is communal. Therefore, the social norm is no longer operative in the society. In this section I am going to explore the equilibrium of economies that satisfy $N \geq \bar{L} / \phi+A$; that is, land is no longer the relatively abundant factor. Assumptions 1 and 2 still hold in this section, but Assumption 3 will be changed to

$$
\text { Assumption 3'. } \quad-1 \leq \rho<0
$$

In the previous section Assumption 3 implied that $\rho$ could take values in the interval $[\bar{\rho}, 0)$, where $\bar{\rho}<-1$. Here I restrict the set to $[-1,0)$ to simplify the analysis. I am going to assume, as in the basic model, that no peasant can become a landowner. 
It is easy to see that in economies in which the size of the population satisfies $\bar{L} / \phi+A \leq N<2 \bar{L} / \phi$, the equilibrium outcome is identical to the one discussed in the previous section. Hence, I focus my analysis on economies in which $N \geq 2 \bar{L} / \phi$.

\subsection{Privatizing All the Land}

Let us assume that the population size satisfies $\frac{2}{\phi} \bar{L} \leq N \frac{\bar{L}}{\phi}\left(\frac{1-\theta}{-\rho \theta}\right)^{-1 / \rho}+A$. The first term of the inequality can be written as $\bar{L} \leq \phi \frac{N}{2}$. The second term of the inequality and Assumptions 1, 2, and $3^{\prime}$ imply that the individuals' preferences for private land are those already described in Section 4. Aristocrats choose $P \in\{N / 2, N-A\}$. Choosing $P=N / 2$ is no longer optimal since the amount of privately owned land would be $L_{\mathrm{p}}(N / 2)=\bar{L}$, and therefore, the aristocrats are better off choosing $P=N$ $-A$.

Proposition 7. For any $N$ such that $\frac{2 \bar{L}}{\phi} \leq N<\frac{\bar{L}}{\phi}\left(\frac{1-\theta}{-\rho \theta}\right)^{-1 / \rho}+A$, the number of private workers is $P=N-A$ and the amount of private land is $L_{\mathrm{p}}=\bar{L}$.

\subsection{Facing the Threat of Total Expropriation}

The scenario is very different for any economy in which $N \geq$ $\frac{\bar{L}}{\phi}\left(\frac{1-\theta}{-\rho \theta}\right)^{-1 / \rho}+A$. In this case the private workers' preferences for private land are not single-peaked. They show a minimum at $\lambda(P)$. Their most preferred outcome is either 0 or $\bar{L}$. The private workers prefer $\bar{L}$ if their number is small enough (so they can be ensured a sufficiently high wage). Let $\nu(N, A)$ be the critical number of private workers such that if $P \leq \nu(N, A)$ the private workers' most preferred outcome is $\bar{L}$ and their most preferred outcome is 0 otherwise. It is shown in the Appendix that $\nu(N, A)$ increases with the size of the population and that, under Assumption $3^{\prime}, \frac{\nu(N, A)}{N}$ decreases with $N$. Therefore, for the aristocrats to keep the land, they have to choose $P \leq \nu(N, A)$ and it needs to be satisfied that $P+A \geq N / 2$. If $N$ is sufficiently high, we have that $\nu(N, A)+A<N / 2$ and the aristocrats are expropriated all the land. Thus, the aristocrats' ability to "divide and conquer" depends on the population density. If the population is too large, the aristocrats cannot offer high enough wages for the peasants to prefer the wage instead the average yield in the communal sector. In this case, although it goes beyond the scope of this paper, it would benefit the aristocrats to give some peasants the right to own land privately to build enough constituency so that they could keep the land. The following propositions summarize these results.

Proposition 8. If $N \geq \frac{L}{\phi}\left(\frac{1-\theta}{-\rho \theta}\right)^{-1 / \rho}+A$ and Assumptions 1, 2, and $3^{\prime}$ hold, given any number $P$ of private workers, the private workers' preferences 
have a minimum at $\lambda(P)$. There exists a number $\nu(N, A)$ such that if $P \leq \nu(N, A)$ the private workers prefer all the land to be privately held. If $P>\nu(N, A)$ they prefer all the land to be communal. For any $N \geq$ $\frac{L}{\phi}\left(\frac{1-\theta}{-\rho \theta}\right)^{-1 / \rho}+A$ the informal worker's preferences are monotonically decreasing with the amount of private land.

Proposition 9. There exists a size of the population, $\hat{N}>\frac{L}{\phi}\left(\frac{1-\theta}{-\rho \theta}\right)^{-1 / \rho}$ $+A$, such that for any $N>\hat{N}$ we have that $\nu(N, A)<\frac{N}{2}-A$. For any $N>\hat{N}$, all the land becomes communal.

\section{CONCLUSION}

This paper provides a rationale for the land reform processes that many Latin American countries have experienced during this century. It focuses on the conflicts of interests that arise within a society as a basis for understanding why a communal ownership regime on expropriated land would be chosen instead of an efficient private ownership system. Two assumptions are key for such conflicts to arise: Land and labor are assumed to be complementary factors and land is the relatively abundant factor. The first assumption is not unreasonable. Cornia (1985) estimates output elasticity of land for a cross section of countries and finds it to be decreasing with the land-labor ratio. An output elasticity decreasing in this ratio is satisfied by a CES production function only if the elasticity substitution parameter $\rho$ is negative. The relative abundance of land is widely acknowledged in the development literature as a key factor to understand the evolution of the agrarian structure in Latin America.

In 1992, the Mexican government changed the Constitution so that the ejido members were allowed to divide the ejidal land and become private owners. In the terms of this model, they were made small owners. To model this evolution of the reform, we should take in account the existence of an urban sector that wants to have inexpensive agricultural goods; thus, they favor giving the peasants the ownership of the land, since it increases the aggregate level of productivity in the agricultural sector. This is a topic for further research.

\section{APPENDIX}

LEMMA 1. The function $\lambda():.(0, N-A) \rightarrow\left(0, L_{m}\right)$ is strictly increasing with $P$ and satisfies $y_{\mathrm{p}}(P, \lambda(P))=y_{\mathrm{c}}(P, \lambda(P))$. The inverse of this function is 
denoted as $\eta($.$) . The amount of private land L_{\mathrm{m}}$ is defined as

$$
\min \left\{\phi\left(\frac{-\rho}{\theta \rho /(1-\rho)-1}\right)^{-1 / \rho}(N-A), \bar{L}\right\} .
$$

Proof. The existence of the function $\lambda\left(\right.$.) in the interval $\left(0, L_{\mathrm{m}}\right)$ is ensured by the implicit function theorem. $L_{\mathrm{m}}$ is the amount of land which satisfies $\lim _{P \rightarrow N-A} y_{\mathrm{p}}\left(P, L_{\mathrm{m}}\right)=\lim _{P \rightarrow N-A} y_{\mathrm{c}}\left(P, L_{\mathrm{m}}\right)$.

Lemma 2. Let $x_{\mathrm{p}}(P), x_{\mathrm{c}}(P)$, respectively, be equal to $\frac{\lambda(P)}{P}, \frac{L-\lambda(P)}{N-A-P}$. Both ratios satisfy $x_{\mathrm{p}}(P) \leq \lambda^{\prime}(P) \leq x_{\mathrm{c}}(P)$ if $\bar{L} \geq(N-A) \phi\left(\frac{-\rho \theta}{1-\theta}\right)^{-1 / \rho}$ and $x_{\mathrm{p}}(P)>\lambda^{\prime}(P)>x_{\mathrm{c}}(P)$ otherwise.

Proof. It is easy to check that $x_{\mathrm{p}}(P) \leq \lambda^{\prime}(P) \leq x_{\mathrm{c}}(P) \Leftrightarrow x_{\mathrm{p}}(P) \leq x_{\mathrm{c}}(P)$. Notice that $x_{i}(P)=-\left[\partial y_{i}(P, \lambda(P)) / \partial P\right] /\left[\partial y_{i}(P, \lambda(P)) / \partial L_{\mathrm{p}}\right], i=\mathrm{p}, \mathrm{c}$. Let us denote $x=\bar{L} /(N-A)$. Let us assume that $L \geq(N-$ $A) \phi(-\rho \theta /(1-\theta))^{-1 / \rho}$ and $x_{\mathrm{p}}(P)>x_{\mathrm{c}}(P)$. Then, $y_{\mathrm{p}}(P, \lambda(P)) / y_{\mathrm{c}}(P, \lambda(P))=y_{\mathrm{p}}\left(1, x_{\mathrm{p}}(P)\right) / y_{\mathrm{c}}\left(1, x_{\mathrm{c}}(P)\right) \geq y_{\mathrm{p}}(1, x) / y_{\mathrm{c}}(1, x)>1$, which contradicts that $y_{\mathrm{p}}(P, \lambda(P)) / y_{\mathrm{c}}(P, \lambda(P))=1$. Hence, $x_{\mathrm{c}}(P) \leq x_{\mathrm{c}}(P)$. The other case is proved in a similar fashion.

Lemma 3. For any given $P \in(0, N-A), x_{\mathrm{p}}(P)$ and $x_{\mathrm{c}}(P)$ satisfy $x_{\mathrm{p}}^{\prime}(P)$ $\cdot x_{\mathrm{c}}^{\prime}(P) \geq 0$. If $x_{\mathrm{p}}^{\prime}(P) \cdot x_{\mathrm{c}}^{\prime}(P)=0$ then $x_{\mathrm{p}}^{\prime}(P)=x_{\mathrm{c}}^{\prime}(P)=0$.

Proof. Visual inspection of the equality $y_{\mathrm{p}}\left(1, x_{\mathrm{p}}(P)\right)=y_{\mathrm{c}}\left(1, x_{\mathrm{c}}(P)\right)$ yields that $x_{\mathrm{p}}(P)$ and $x_{\mathrm{c}}(P)$ move in the same direction.

LEMmA 4. If $\bar{L} \geq(N-A) \phi\left(\frac{1-\theta}{-\rho \theta}\right)^{-1 / \rho}$ the ratios $x_{\mathrm{p}}(P)$ and $x_{\mathrm{c}}(P)$ are strictly increasing functions of $P$ and are decreasing otherwise.

Proof. It is easy to check that $\operatorname{sign}\left(x_{\mathrm{p}}^{\prime}(P)\right)=\operatorname{sign}\left(\lambda^{\prime}(P) \cdot P-\lambda(P)\right)=$ $\operatorname{sign}\left(\lambda^{\prime}(P)-x_{\mathrm{p}}(P)\right)$. Thus, if $\bar{L}>(N-A) \phi\left(\frac{1-\theta}{-\rho \theta}\right)^{-1 / \rho}$ Lemma 2 ensures that $\lambda^{\prime}(P)-x_{\mathrm{p}}(P)>0$, which implies that $\operatorname{sign}\left(x_{\mathrm{p}}^{\prime}(P)\right)>0$ for all $P$. Lemma 3 implies that $\operatorname{sign}\left(x_{\mathrm{c}}^{\prime}(P)\right)>0$. The rest of the cases are proved in a similar way.

Proof of Proposition 1. For any $L_{\mathrm{p}} \geq \lambda(P), y_{\mathrm{p}}(P,$.$) strictly increases$ with $L_{\mathrm{p}}$ since $N_{\mathrm{p}}=P$. For any $L_{\mathrm{p}}<\lambda(P)$ the number of private workers that stay in the private sector is $N_{\mathrm{p}}=\eta\left(L_{\mathrm{p}}\right)$, which satisfies $\lambda\left(N_{\mathrm{p}}\right)=L_{\mathrm{p}}$. The wage only depends on the land-labor ratio $L_{\mathrm{p}} / \eta\left(L_{\mathrm{p}}\right)$. Assumptions 1 and 2 imply that $N<2 \bar{L} / \phi$. This inequality and Assumption 4 imply that $\bar{L}>(N-A) \phi\left(\frac{1-\theta}{-\rho \theta}\right)^{-1 / \rho}$. Lemma 4 implies that $L_{\mathrm{p}} / \eta\left(L_{\mathrm{p}}\right)$ increases with $L_{\mathrm{p}}$; therefore $y_{\mathrm{p}}\left(P, L_{\mathrm{p}}\right)$ strictly increases with $L_{\mathrm{p}}$.

Proof of Proposition 2. For any $L_{\mathrm{p}} \geq \lambda(P), y_{\mathrm{c}}(P,$.$) strictly decreases$ with $L_{\mathrm{p}}$. For any $L_{\mathrm{p}}<\lambda(P)$ Lemmas 3 and 4 and Proposition 1 yield that 
$y_{\mathrm{c}}$ strictly increases with $L_{\mathrm{p}}$. Thus, $y_{\mathrm{c}}(P,$.$) has a maximum at L_{\mathrm{p}}=\lambda(P)$.

Proof of Proposition 3. Assumption 2 implies that $y_{\mathrm{p}}(P, \phi P)>$ $y_{\mathrm{c}}(P, \phi P)$ for any $P \in(0, N-A)$. This implies that $\phi P>\lambda(P)$ for any $P \in(0, N-A)$. Recall that $\phi P$ satisfies $\partial y_{\mathrm{a}}(P, \phi P) / \partial L_{\mathrm{p}}=0$, for any $P \in(0, N-A)$. Assumption 4 implies that $\phi P<\bar{L}$. Thus, for any $L_{\mathrm{p}} \geq$ $\lambda(P), y_{\mathrm{a}}\left(P, L_{\mathrm{p}}\right)$ has a maximum at $\phi P$. For any $L_{\mathrm{p}}<\lambda(P)$ concavity of $y_{\mathrm{a}}$ with respect to $L_{\mathrm{p}}$ ensures that $d y_{\mathrm{a}}\left(P, L_{\mathrm{p}}\right) / d L_{\mathrm{p}}=\partial y_{\mathrm{a}}\left(P, L_{\mathrm{p}}\right) / \partial L_{\mathrm{p}}+$ $\partial y_{\mathrm{a}}\left(P, L_{\mathrm{p}}\right) / \partial\left(\eta\left(L_{\mathrm{p}}\right)\right) \cdot \eta^{\prime}(P)>\partial y_{\mathrm{a}}\left(P, L_{\mathrm{p}}\right) / \partial L_{\mathrm{p}}>\partial y_{\mathrm{a}}(P, \phi P) / \partial L_{\mathrm{p}}=0$.

Thus, $y_{\mathrm{a}}(P,$.$) is strictly increasing for any L_{\mathrm{p}}<\lambda(P)$ and it has a maximum at $\phi P$.

Proof of Proposition 4. Apply the median voter theorem.

Proof of Proposition 5. $y_{\mathrm{a}}(N / 2, \phi N / 2) \geq y_{\mathrm{a}}(N-A, \bar{L})$ if $A \geq N_{\mathrm{a}}(N)$ where $N_{\mathrm{a}}(N)$ is equal to

$$
N-\left((1-\rho)\left(\frac{N}{2}\right)^{\rho / 1-\rho}\left(\frac{\bar{L}}{\phi}\right)^{-\rho^{2} /(1-\rho)}+\rho\left(\frac{\bar{L}}{\phi}\right)^{\rho}\right)^{1 / \rho}
$$

$N_{\mathrm{a}}(N)$ is bounded above by $\frac{1}{2} N$ and increases with $N . N_{\mathrm{a}}(N) \leq 0$ if $(1-\rho) 2^{-\rho /(1-\rho)} \Phi^{-\rho^{2} /(1-\rho)} \leq 1-\rho \Phi^{\rho}$, where $\Phi \equiv \frac{L}{\phi N}$. For $\Phi=1,(1-$ $\rho) 2^{-\rho /(1-\rho)} \Phi^{-\rho^{2} /(1-\rho)}>1-\rho \Phi^{\rho}$. Thus, there exists $\chi>1$, such that for any $\Phi \geq \chi$, the inequality is satisfied. Thus, for any $\phi \chi \leq \bar{L} / N$, $y_{\mathrm{a}}(N / 2, \phi N / 2) \geq y_{\mathrm{a}}(N-A, \bar{L})$ for any $A$.

Proof of Proposition 6. It follows from the proof of Proposition 4.

Proof of Proposition 7. Since $N<\frac{L}{\phi}\left(\frac{1-\theta}{-\rho \theta}\right)^{-1 / \rho}+A$, Lemmas 2, 3, and 4 imply that the private and communal workers' preferences for private land are those described in Propositions 1 and 2. Assumption 2 implies that aristocrats' preferences are those described in Proposition 3. From Proposition 6 it follows that the number of private workers is either $N / 2$ or $N-A$. Since $N \geq \frac{2 \bar{L}}{\phi}$ it follows that $\bar{L} \leq \phi N / 2$. Since $y_{\mathrm{a}}$ is strictly increasing with the number of private workers, it follows that $P=N-A$ and $L_{\mathrm{p}}=\bar{L}$.

Proof of Proposition 8. First, I prove the result concerning the private workers preferences on private land. Lemmas 2,3 , and 4 imply that if $N$ $>\frac{\bar{L}}{\phi}\left(\frac{1-\theta}{-\rho \theta}\right)^{-1 / \rho}+A$, for any $L_{\mathrm{p}} \leq \lambda(P), y_{\mathrm{p}}\left(P, L_{\mathrm{p}}\right)$ decreases with $L_{\mathrm{p}}$. Therefore $y_{\mathrm{p}}$ has a minimum at $L_{\mathrm{p}}=\lambda(P)$. The private workers' most preferred outcome is either 0 or $\bar{L}$. Direct comparison of $y_{\mathrm{p}}(P, 0)$ and 
$y_{\mathrm{p}}(P, \bar{L})$ shows that $y_{\mathrm{p}}(P, \bar{L}) \geq y_{\mathrm{p}}(P, 0)$ if $P \leq \nu(N, A)$ and $y_{\mathrm{p}}(P, \bar{L})<$ $y_{\mathrm{p}}(P, 0)$ otherwise. The expression of $\nu(N, A)$ is

$\nu(N, A)$

$$
=L\left(\frac{\left(\frac{\theta}{1-\gamma}\right)^{\rho /(1-\rho)} \cdot\left(\gamma\left(\frac{\bar{L}}{N-A}\right)^{\rho}+(1-\gamma)\right)^{1 /(1-\rho)}-(1-\gamma)}{\gamma}\right)^{-1 / \rho} .
$$

The result for the communal workers' preferences follows from Lemmas 2, 3, and 4, and Propositions 2 and 8.

Proof of Proposition 9. First, I prove the existence of $\hat{N}$. The derivative of $\frac{\nu(N, A)}{N}$ can be expressed as

$$
\left(\frac{\gamma}{1-\gamma}\right)^{1 / \rho} \cdot \frac{\bar{L}}{N^{2}} \cdot\left[\theta^{\rho /(1-\rho)}\left(\frac{\gamma x^{\rho}+(1-\gamma)}{1-\gamma}\right)^{1 /(1-\rho)}-1\right] . H,
$$

where $x=\bar{L} /(N-A), H$ is

$$
1-\theta^{\rho /(1-\rho)} \cdot\left(\frac{\gamma x^{\rho}+(1-\gamma)}{1-\gamma}\right)^{1 /(1-\rho)} \cdot\left(\frac{\Psi \gamma x^{\rho}+(1-\gamma)}{\gamma x^{\rho}+(1-\gamma)}\right),
$$

and $\Psi=\frac{(-\rho /(1-\rho)) N-A}{N-A}$. The three first terms of the derivative are always positive and $H$ is negative at $x=\phi\left(\frac{-\rho \theta}{1-\theta}\right)^{-1 / \rho}$. $H$ increases monotonically with $N$ and for $N$ sufficiently high, $H \rightarrow 1-\theta^{\rho /(1-\rho)} \cdot \frac{-\rho}{1-\rho}$, which is less than zero under Assumptions 2 and $3^{\prime}$. Thus, $H$ is always negative. It implies that the derivative of $\frac{\nu(N, A)}{N}$ is always negative. The limit of $\frac{\nu(N, A)}{N}$ is 0 . Therefore, there exists $\hat{N}$ such that for any $N>\hat{N} \nu(N, A)<N / 2$.$A$ is satisfied. Hence, for any $N \geq \hat{N}$ and regardless of aristocrats' preferences all the land becomes communal.

\section{REFERENCES}

Barraclough, S., and Collarte, J. C. (1973). Agrarian Structure in Latin America. Boston: Heath.

Bazant, J. (1977). "Hacendados, Peons and Tenants in San Luis Potosí, North of México 1822-1910," in Land and Labor in Latin America, (K. Duncan and I. Rutledge, Eds.), Cambridge, UK: Cambridge Univ. Press.

Besley, T., and Burgess, R. (1998). "Land Reform, Poverty Reduction and Growth: Evidence from India," mimeo. 
Binswanger, H. P., Deininger, K., and Feder, G. (1993). “Agricultural Land Relations in the Developing World," American Journal of Agricultural Economics 75, 1242-1262.

Binswanger, H. P., Deininger, K., and Feder, G. (1995). "Power, Distortions and Reform in Agricultural Land Markets," in Handbook of Development Economics, Vol. 3B (J. Behrman and T. N. Srinivasan, Eds.), Amsterdam/New York: Elsevier.

Brannon, J., and Baklanoff, E. N. (1984). "The Political Economy of Agrarian Reform in Yucatán, México,” World Development 12(11/12), 1131-1141.

Cornia, G. (1985). "Farm Size, Land Yields, and the Agricultural Production Function: An Analysis for Fifteen Developing Countries," World Development 13(14), 513-534.

De Janvry, A. (1981). The Agrarian Question and Reformism in Latin America, Baltimore: John Hopkins Univ. Press.

De Soto, H. (1989). The Other Path: The Invisible Revolution in the Third World, New York: Harper Row.

Ekstein, S., Donald, G., Horton, D., and Carroll, T. (1978). "Land Reform in Latin America: Bolivia, Chile, México, Peru, and Venezuela," World Bank Staff Working Paper 275.

Grossman, H. (1994). "Production, Appropriation, and Land Reform," American Economic Review 84(3), 705-712.

Heath, D., Erasmus, C., and Buechler, H. (1969). Land Reform and Social Revolution in Bolivia, Praeger Special Studies in International Economics and Development, New York: Praeger.

Horowitz, A. (1993). "Time Paths of Land Reform: A Theoretical Model of Reform Dynamics," American Economic Review 83(4), 1003-1010.

Kay, C. (1982). "Achievements and Contradictions of the Peruvian Agrarian Reform," Journal of Development Studies 18(2), 141-170.

Martinez Hernandez, R. (1992). "México's Agrarian Reform and Its Influence on the Economic Growth of Agriculture," Ph.D. Dissertation, Vanderbilt University.

Mendieta y Nuñez, L. (1937). El Problema Agrario de Mexico, Mexico: Ediciones, Porrua.

Moene, K. O. (1992). "Poverty and Landownership," American Economic Review 82(1), $52-64$.

Mueller, D. (1989). Public Choice II, Cambridge, UK: Cambridge Univ. Press.

Nguyen, D. T., and Martinez Saldivar, M. L. (1979). "The Effects of Land Reform on Agricultural Production, Employment and Income Distribution: A Statistical Study of Mexican States, 1959-69," The Economic Journal 89, 624-635.

Otsuka, K., Chuma, H., and Hayami, Y. (1992). "Land and Labor Contracts in Agrarian Economies: Theories and Facts,” Journal of Economic Literature 30, 1965-2018.

Ray, D., and Streufert, P. A. (1993). "Dynamic Equilibria with Unemployment due to Undernourishment," Economic Theory 3, 61-85.

Ray, D. (1998). Development Economics, Princeton, NJ: Princeton Univ. Press.

Sadoulet, E. (1992). "Labor-Service Tenancy Contracts in a Latin American Context," American Economic Review 82(4), 1031-1042.

Wilkie, J. W. (1974). Measuring Land Reform, Los Angeles: UCLA Latin American Center, Univ. of California, Los Angeles.

Wilkie, J. W. (1993). Statistical Abstract of Latin America, Vol. 30, Part 1, Los Angeles: UCLA Latin American Center, University of California, Los Angeles.

Yates, P. L. (1981). "Mexican Land Reform: A Comment," The Economic Journal 91, 745-752. 